\title{
Paper in Motion: Communication, Knowledge and Power Case Studies for an Interdisciplinaty Approach
}

\author{
José MARÍA PÉrez FERnÁNDEZ \\ University of Granada
}

\section{Introduction}

\author{
Her lap was full of writs and of citations, \\ Of processes, of actions and arrests, \\ Of bills, of answers, and of replications, \\ In courts of Delegats, and of requests, \\ Grieuing the simple sort with great vexations: \\ She had resorting to her as her guests, \\ Attending on her circuits and her iourneys, \\ Scriu'ners and clarks, lawyers and atturneys.
}

\section{Ludovico Ariosto, Orlando Furioso ${ }^{1}$}

The allegory of Discord in Ariosto's Orlando Furioso appears as a female figure bearing a morass of legal papers and followed by a host of scribes, clerks, lawyers, attorneys and notaries. It is one among several samples in literature and the arts which represent the new contractual habits that had emerged towards the end of the Middle Ages. It was also part of a larger cluster of changes in communication and trade which some have described as a revolution. ${ }^{2}$ The contractual exchanges registered on papers like those featured in Discord's lap were meant to weave a fiduciary network based on professional practice and documents whose authenticity and validity were legitimised through the use of seals, intricate signatures and a series of other protocols that also guaranteed a degree of homogeneity for their efficient communication.

The theologian Jean Gerson (1363-1429) was among those who sought to look into the nature of these habits with a short treatise titled De contractibus (1420). Gerson claims that

\footnotetext{
1 JOHn HARINGTON, trans. Orlando Furioso in English Heroicall Verse (London: Richard Field, 1591), canto XIV.73, Discord. 'Di citatorie piene, e di libelli, / D'essamini, e di carte di procure / Hauea le mani, e il seno; e gran fastelli / di chiose, di consigli e di letture; / per cui le facultà de' pouerelli / non sono mai ne le città sicure. / Hauea dietro, dinanzi, e d'ambi i lati, / Notai, Procuratori, \& Auuocati.' LudovicO Ariosto, Orlando Furioso (Venice: Vincenzo Valgrisi, 1560), canto XIV.84, Discordia.

${ }^{2}$ Harold InNis, Empire and Communications (Toronto: Dundurn Press, 2007), 150-51. For Innis on paper, its invention in China, its spread throughout Asia and its arrival in Europe, see 'The Coming of Paper,' in Harold Innis's History of Communications. Paper and Printing. Antiquity to Early Modernity, eds William J. Buxton, Michael R. Cheney and Paul Heher (Lanham, MD: Rowman \& Littlefield, 2015), 15-56. The first part of LUCIEN POLASTRON's Le Papier, 2000 ans d'bistoire et de savoir-faire (Paris: Imprimerie Nationale, 1999) provides an interesting and beautifully illustrated account of paper in China, the rest of Asia and its arrival in medieval Europe. The most recent contribution on important aspects of paper with a focus on the British Isles is ORIETTA DA ROLD's Paper in Medieval England (Cambridge, UK: Cambridge University Press, 2020).
}

Cromohs (Cyber Review of Modern Historiography), ISSN 1123-7023, 23/2020

C 2020 The Author. This is an open access article published by Firenze University Press under the terms of the Creative Commons Attribution Licence, which permits use, distribution and reproduction in any medium, provided the original work is properly cited

DOI: $10.36253 /$ cromohs-12025 
the contract both establishes and legitimises civic life. It provides a fiduciary framework for human communities in which mutual trust in all sorts of social and commercial exchanges are established by means of documents and practices regulated by positive law. ${ }^{3}$ But far from a source of social harmony and creditable exchanges, literature and the visual arts frequently depicted such contractual relations as causes and symptoms of deceit, discord and exploitation. This appears in visually striking terms in Marinus van Reymerswaele's The Lawyer's Office (1545) and Brueghel the Younger's Village Lanyer (1621). ${ }^{4}$

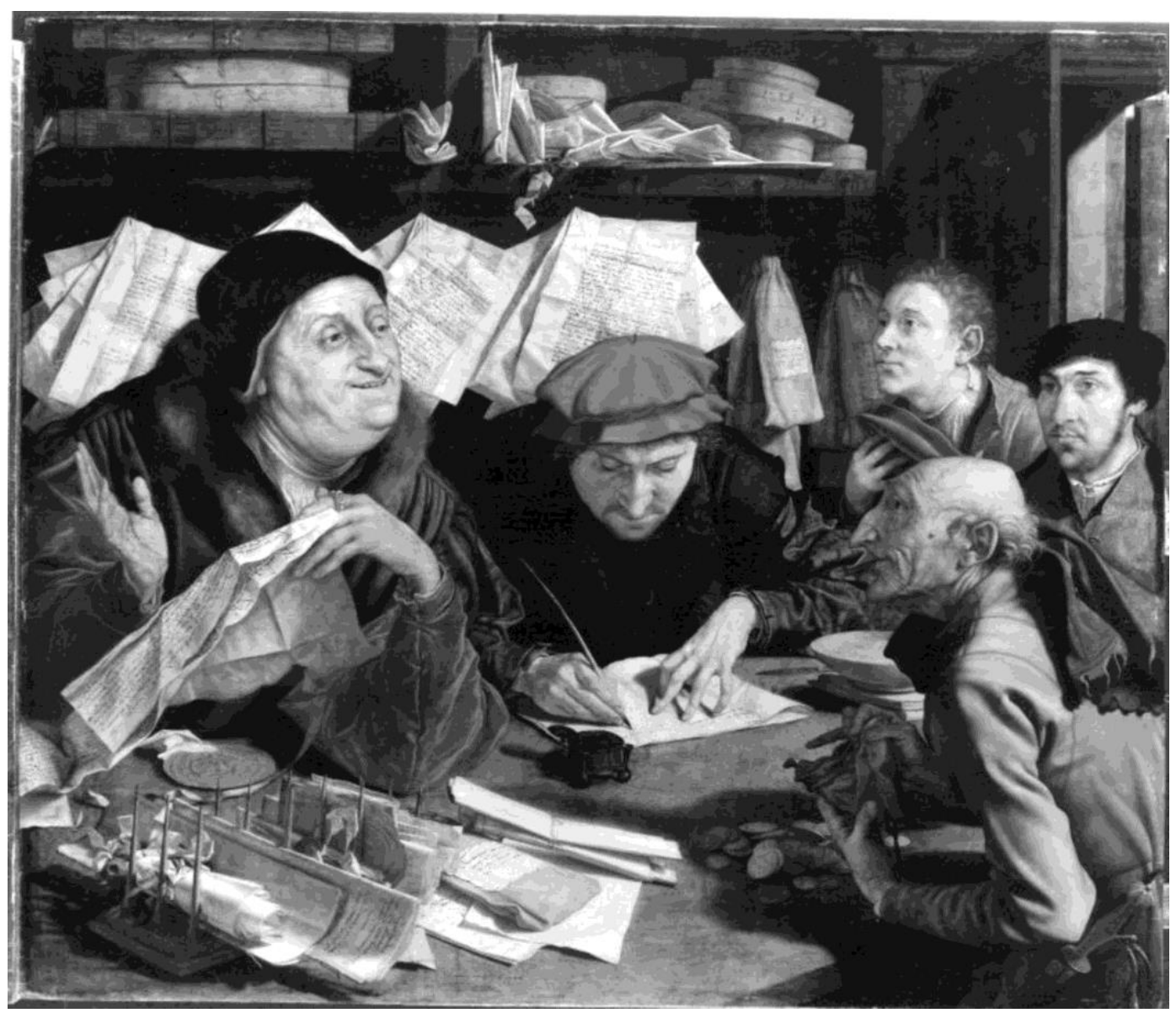

Figure 1. Marinus van Reymerswaele, Ein Notar (The Lanyer's Office), 1542, Bavarian State Painting Collections, Alte Pinakothek, München, https://www.sammlung.pinakothek.de/. Reproduced under Creative Commons Attribution-ShareAlike 4.0 International (CC BY-SA 4.0) license. A digitised reproduction of the 1545 version is available through the New Orleans Museum of Art's website, https:// noma.org/collection/the-lawyers-office/.

3 The full text of De contractibus can be found in GERSON's Opera Omnia, vol. III (Antwerp, 1706), cols. 165-96. The passages in question are in cols. 167-68.

${ }^{4}$ Similar visual treatment of the ubiquity of paper can be found in several other paintings, from JAN GOSSAERT's Portrait of a Merchant, ca. 1530, at National Gallery of Art, https:/ /www.nga.gov/collection/artobject-page.50722.html, to REMBRANDT's moneylender, The Parable of the Rich Fool, or the Money Changer, 1627, at RKD - Netherlands Institute for Art History, https://rkd.nl/en/explore/images/46372. Here and henceforth links were last accessed November 14, 2020. 


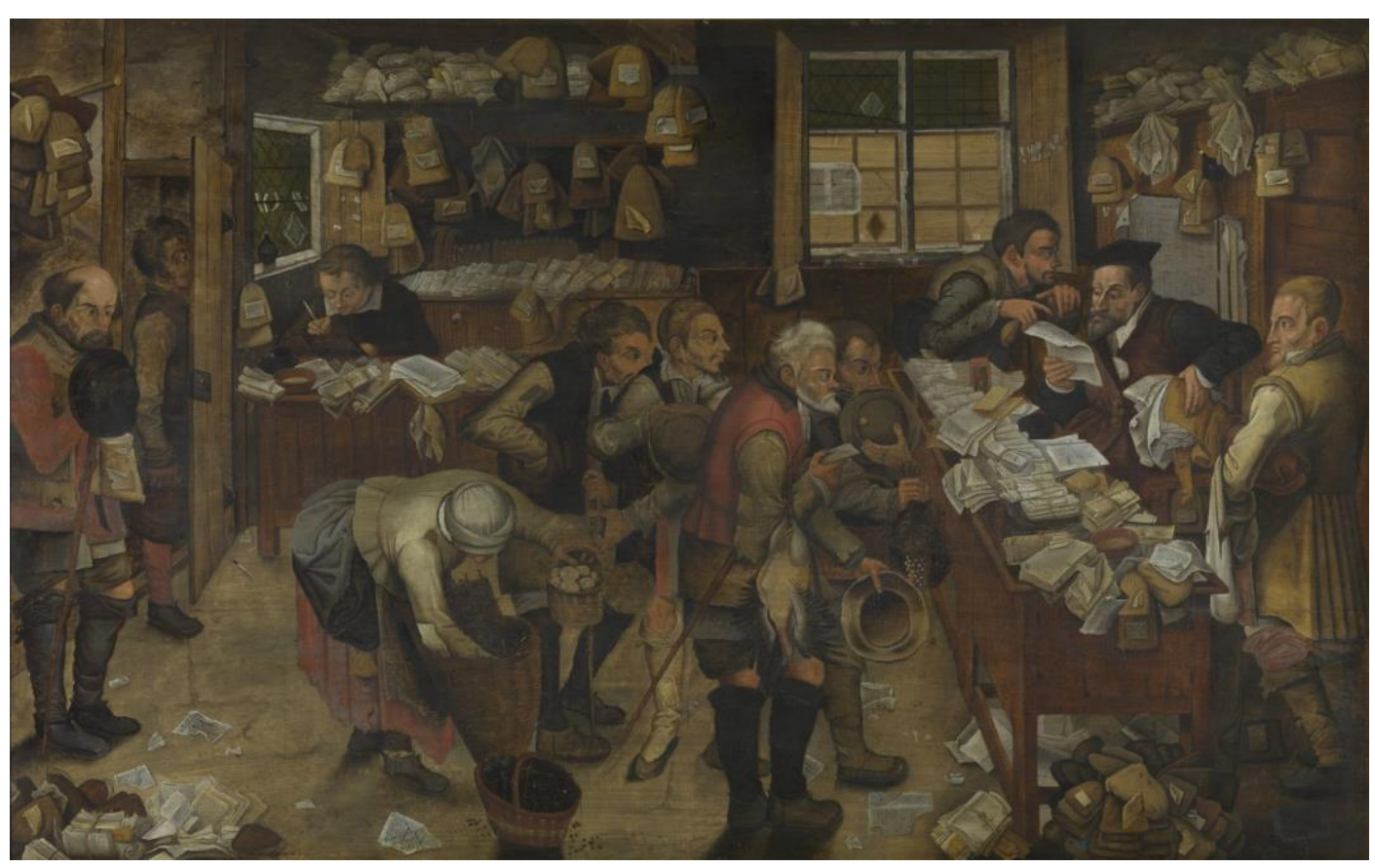

Figure 2. Pieter Brueghel the Younger, Village Lawyer (1621). Source: Museum of Fine Arts, Ghent, www.artinflanders.be, photo Hugo Maertens. Used with permission.

The material substance of paper in and of itself is of course useless for all these purposes unless it serves as the vehicle for symbolic systems, such as script in the case of natural languages or a code for numerical notation in mathematics. Paper is nothing without the semiotic performance that it serves to materialise or the formal protocols that facilitate the communication of the information recorded on it. The arrival of paper in Europe alongside the adoption of Arabic numerals around the twelfth century, the development of arithmetic techniques for the collection, measurement and quantification of economic and scientific data, and the use of paper as an inexpensive, modular and highly mobile medium on which to register, combine and exchange the growing wealth of information and knowledge that was produced towards the end of the Middle Ages, all decisively contributed not just to the emergence of complex political, administrative and legal structures, but also to a revolution in disciplines and practices like astronomy, cartography and navigation. The parallel emergence of paper-based finance and banking also resulted in the gradual dematerialisation of the economy. The sort of knowledge and abstract credit thus produced became in turn the lifeblood for the practice of global trade and imperial hegemony. 


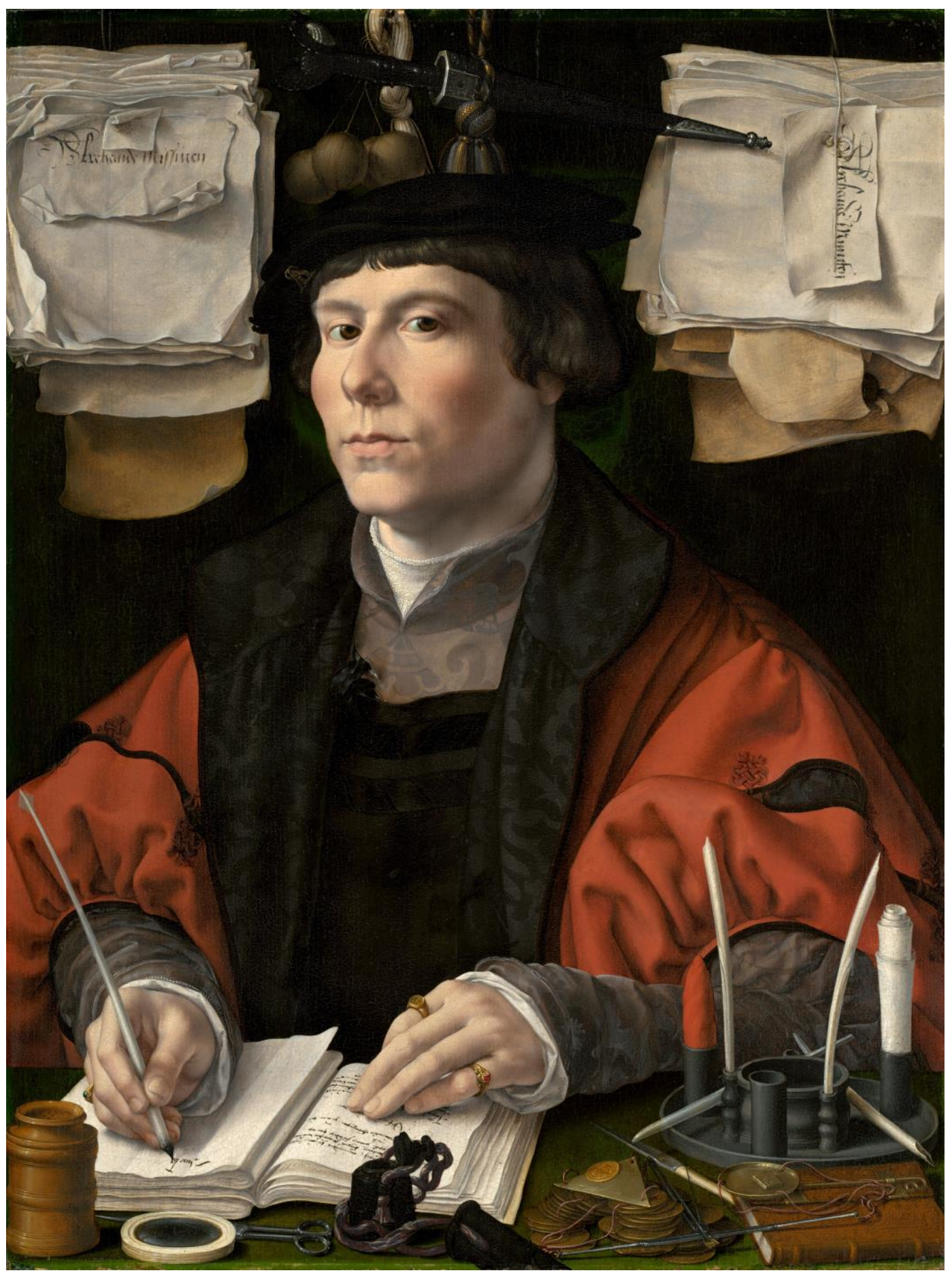

Figure 3. Jan Gossaert, Portrait of a Merchant, ca. 1530, Ailsa Mellon Bruce Fund, National Gallery of Art, https://www.nga.gov/collection/art-object-page.50722.html. Open access image. 


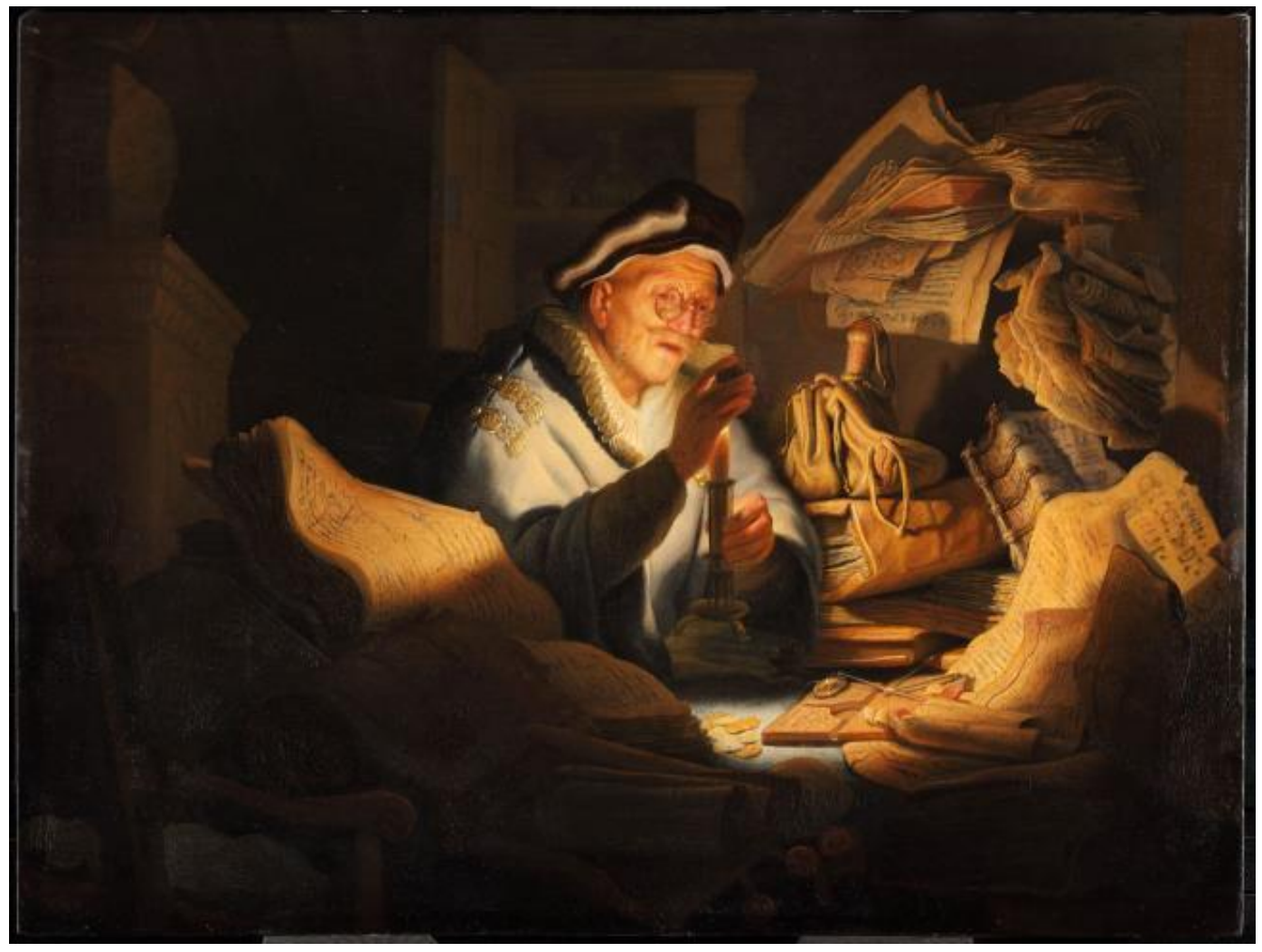

Figure 4. Rembrandt, The Parable of the Rich Fool, or the Money Changer, 1627, via RKD Netherlands Institute for Art History, https://rkd.nl/en/explore/images/46372. Reproduced under Creative Commons Attribution-NonCommercial-ShareAlike 4.0 International (CC BY-NC-SA 4.0) license.

The close relation of the new contractual culture with the conduct, legitimation and regulation of trade and finance is further illustrated by one of the earliest print editions of Gerson's De contractibus, which was published in Cologne in 1483-84 along with two other essays on contracts and a treatise on currency. De moneta, penned by the French polymath Nicholas Oresme (1323-85), proves that coins were another type of documentary genre, inscribed on a different sort of medium, whose performative value, like that of legally binding contracts, relied on the combination of a social compact and a central authority that enforced and legitimised it. ${ }^{5}$

\footnotetext{
${ }^{5}$ The other two essays on contracts were penned by Henry of Langenstein and Henry of Oyta, two of Oresme's disciples. Opera. Add: Henricus de Hassia: De contractibus; Henricus de Hoyta: De contractibus; Nicolaus Oresme: De moneta ([Cologne]: Johann Koelhoff, the Elder, 1483-84), see also 'Gerson, Johannes: Opera. Add,' entry in BRITISH LIBRARY, Incunabula Short Title Catalogue: The International Database of 15thcentury European Printing, https:// data.cerl.org/istc/ig00185000: 'Oresme takes the Aristotelian view that a coin is a definite weight of precious metal, the quantity and fineness of which is guaranteed by the stamp of the authority issuing it. The currency does not belong to the issuing authority, but to the public which uses it for the purpose of exchange of goods. The prince has therefore no right to vary the standard or the weight or (if two metals are, as usually, employed) the bimetallic ratio; though the last
} 
These few examples prove that a proper approach to paper requires an interdisciplinary perspective which can take into close consideration its entanglement with other media, a variety of cultural phenomena, and historical developments of very complex and heterogeneous natures. The history of paper and its arrival from China and through the Muslim world - including what at that time was still the Muslim south of Europe - across the Mediterranean into Europe around the twelfth century, and eventually on to the rest of the globe, constitutes in itself an interesting case study for the material mobility of a new medium that contributed to a revolution in communication, knowledge and administration. The availability of paper, its inexpensive nature and its capacity to register and circulate data swiftly and efficiently facilitated a new age of information towards the end of the Middle Ages.

Before the new inventions in electronic media that followed the Industrial Revolution, paper was the essential technology employed in regional and international communication networks, as well as in the administration of a host of institutions. ${ }^{6}$ Only now, more than 700 years after its arrival in Europe, has paper found a serious competitor in the new digital format. This essay aims to provide a brief, and hence non-exhaustive, account of some relevant approaches to paper which can contribute to an understanding of its cultural history, alongside its role in the history of communication and media. It will do so by surveying a few case studies which illustrate the presence of paper in momentous political, economic and cultural developments, and which also contemplate it as both a material medium and a trope involved in the mobility of objects, people and ideas.

The following pages will consist of a few snapshots with episodes in the cultural history of paper in the West. They show its role in the establishment of the administrative and political architecture of the modern state, the practice of international trade, and the emergence of banking and finance. They will also contemplate paper as the vehicle for modular epistemic units used as building blocks for the articulation of knowledge into larger discursive structures, and finally its function as the semiotic vehicle for the codification of the emotional capital that brings about a sense of common identity in human communities.

Rather than the use of a medium like paper, it is the new technology of print that has traditionally been perceived as a major turning point in the history of communication. More recent historians of paper like Lothar Müller instead propose a new interpretation that brings paper to the foreground as the facilitator of a semiotic space with the potential to materialise a multitude of contents. Müller seeks, for example, to go beyond the traditional manuscript / print dichotomy by proposing a

may be done if the relative value of the metals is materially altered by a new source of supply. And any necessary alteration must be by agreement of the whole community.' NICHOLAS ORESME, The De moneta of Nicholas Oresme and English Mint Documents, translated with introduction and notes by CHARLES JOHNSON (London: Nelson \& Sons, 1956), x-xi.

6 On the concept of communications revolutions, see WOLFGANG BEHRINGER, 'Communications Revolutions: A Historiographical Concept,' German History 24 (2006): 333-74. 
new typology of paper formats based on two distinctive pairs: printed vs. unprinted and bound vs. unbound. Modern books are the result of combining the printed and bound formats, whereas most letters and documents tend to be unbound and unprinted. Pamphlets and flyers tend to be printed and unbound, whereas traditional manuscript books shared the unprinted and bound formats with notebooks, commonplace books, catalogues, diaries and logs. ${ }^{7}$

Until the arrival of digital media, one of the most important uses of paper was for documents, and their ubiquity led to a misleading identification of their materiality with their documenting function. The media historian Lisa Gitelman stresses that, as a semiotic and epistemic unit, the document constitutes a category above paper. There are documents in a variety of other media, including not just wood, stone or parchment (to name but a few), but artefacts with a common practical use which also have the potential to be semiotically charged. In other words, the paper document is just part of a larger typology of semiotic instruments which are used to register and communicate information. The difference between a mere artefact or an object (be it a piece of paper, or any other sort of thing) and a document is that the document is contextualised, framed and semiotically mobilised to serve a purpose. Documenting is a social and epistemic practice: as Gerson suggested, the binding performative power of contractual documents brought the texture of civic communities into existence. ${ }^{8}$ But in contrast to the somewhat idealistic way in which Gerson, or soon after him civic humanism, described the contract - that is, as a horizontal compact of sorts among citizens somewhat distantly overseen by a benevolent ruler - paper also had the power to become a Trojan horse by means of which the administrative structures of power and their public instruments could and did infiltrate the private realms of individuals and their business. This is why paper is part of the semiotic cluster that makes up Ariosto's allegory of Discord, and why it features in Reymerswaele and Brueghel's iconic critiques of contractual society and its excesses.

Users tend to identify the material substance of a medium with the contents it registers, and paper has been certainly perceived as being one with the information it records and the purposes it serves. The French title of Derrida's collection of essays, Papier machine, reminds us that beyond its sheer materiality - as well as the revealingly ambiguous trope in Derrida's original title - the material formats and the functions of paper are inseparable from both their social and cultural environments, and the

${ }^{7}$ Lothar MÜlLer, White Magic: The Age of Paper (Cambridge, UK and Malden, MA: Polity Press, 2014), 82. On notebooks and paper, see AnKe TE HEESEN, 'The Notebook: A Paper-Technology,' in Making Things Public: Atmospheres of Democracy, Bruno LATOUR and PETER WEIBEL, eds (Cambridge, MA: MIT Press, 2005), 582-89.

${ }^{8}$ On this definition of the document, see SUZANnE BRIET, What is Documentation?, trans. Ronald E. Day, Laurent Martinet and Hermina G. B. Anghelescu (Lanham, MD: Scarecrow, 2006) and LiSA GITELMAN, Paper Knowledge: Toward a Media History of Documents (Durham and London: Duke University Press, 2014), chapter 1. 
practical functions for which this medium first came into existence and within which it then evolved. ${ }^{?}$

In our days, one of the most remarkable expressions of paper as a trope is the reference to undocumented immigrants as sans-papiers or its newly coined English equivalent, paperless. ${ }^{10}$ Closely related to the term green card, the synecdoche here is double: in the first place the medium stands for the legal data it records and their value. For immigrants, on top of its essentially legal function, the paper document has a financial, political and potentially also emotional value. Papers become the key for their incorporation into the civic community since they grant them the status of citizen and all the rights and benefits that come with it. In contrast, the paperless live in a legal and political limbo, in which the absence of the sanctioning value of papers prevents them from integration within the political-administrative structures and also from entering the social spaces of the community into which they would like to be admitted.

\section{Administration and Empire}

Harold Innis viewed paper as one among different media that determined the nature of empires, since their vast political and administrative structures need to rely on efficient communication networks. Durable and heavy media like stone, clay or parchment contributed to civilisations that emphasised time and tended to be run by centralised institutions. They are typical of long-lasting but space-limited political communities like Egypt or Babylon. The use of lighter media like papyrus or paper, on the other hand, favours decentralisation and more hierarchical institutions. And given their mobility, these media also have the potential to generate more complex and dynamic administrative networks whose branches can reach much further. ${ }^{11}$

Paper started to be used for administrative purposes immediately after its arrival in Europe: in the early thirteenth century the Sicilian chancery of the Holy Roman Emperor Frederick II worked with paper provided by Arab merchants. Another Mediterranean monarch, James I of Aragon, used the Arab paper mills on the east coast of the Iberian peninsula which had come under his power after the conquest of Valencia in 1238 for his administrative correspondence, for the establishment of an aulic archive, and also for the registration and reproduction of portolan charts. ${ }^{12}$

In 1231, Frederick II issued a legal code which stressed that all important decrees and laws (instrumenta publica) were to be recorded, copied and distributed on parchment, which emphasises the fact that whereas the inexpensive and light nature of paper made

\footnotetext{
${ }^{9}$ Papier machine does not mean paper machine, as the original title was translated into English, but 'typing paper, or any of its more recent equivalents such as printer paper,' RACHEL BOWLBY, 'Translator's Note,' in JaCQues DerridA, Paper Machine, trans. Rachel Bowlby (Stanford, CA: Stanford University Press, 2005), ix-x.

${ }^{10}$ See for example Charlotte Alfred, “'We want to build a life:” Europe's Paperless Young People Speak Out, The Guardian, August 3, 2020, https://www.theguardian.com/world/2020/aug/03/europe-paperlessyoung-people-speak-out-undocumented-dreamers.

${ }^{11}$ INNIS, Empire and Communications, 26-27.

12 On the pioneering use of paper by James I, see ROBERT IGNATIUS BURNS, Society and Documentation in Crusader Valencia (Princeton, NJ: Princeton University Press, 1985).
} 
it extremely useful for common everyday tasks, more durable media, such as parchment, were preferred when it came to recording important texts that needed to last. Like the knots in a reticular structure, Frederick's parchment documents were meant to hold together the vast networks of the imperial administration, as they also established the semiotic protocols and the rules that ran the entire system. In contrast, paper worked as the fast, disposable and dynamic medium by means of which data and information, the lifeblood of the body politic, circulated throughout the extensive bureaucracy that sustained the power of the monarch over all of his territories. ${ }^{13}$

The way in which the archive of the Castilian monarchy was established in the early years of the sixteenth century reveals some very interesting facts about imperial archives. The lawyer Diego de Salmerón was appointed on 23 June 1509 as keeper and custodian of all the charters and privileges of the crown. His job included gathering all the relevant documents, making official copies, and developing a system for their efficient storage and retrieval. Three identical archives were to be created: two of them in Valladolid and Granada, which were the sites of the two permanent chancillerias (royal high courts) in the kingdom, whereas Salmerón himself would carry the third as he followed the itinerant court.

The archive created by Diego de Salmerón was the direct forerunner of the archive of the first global empire run by paper. As one of the most important repositories of documentary information about the Hispanic monarchy, the Archive of Simancas and its papers constitute excellent case studies, on the one hand, for the complex macro-economic and administrative structures that were generated as a result of the gradual expansion of trade and finance on a global level and, on the other, the creation of the modern state. The age of exploration, which, inter alia, had been made possible by the circulation of astronomical and cartographical data and information based on paper, then opened new paths for imperial conquest and expansion whose management relied on a sophisticated bureaucratic machine based on the use of paper and its circulation throughout domestic and global networks.

The early seventeenth-century historian Lorenzo Vander Hammen y León stressed Philip II's investment in infrastructure and personnel with a view to the collection and coordination of his papers in Simancas. The cubo, or strongbox, at the core of the archive held the documentary foundations for the entire legal and administrative architecture of the state and its territories. It contains, says Vander Hammen, documents concerning the Conquest of Granada, the Indies, the rights to the crowns of Naples, Navarre, Portugal, Siena and Sicily, plus the foundational charter of the Holy Inquisition, the wills and testaments of kings, and peace agreements with France, Moorish kings and the house of Austria, among many others, including 'papeles de razón de Estado. ${ }^{14}$ Philip II is an excellent example of the oscillation between the centralising tendencies of power, on the one hand, and its unavoidable

13 MÜlleR, White Magic, 34 ff. q.v. for further details.

14 LORENZO VANDER HAMMEN Y LEÓN, Don Filipe el prudente, segundo deste nombre, rey de las Españas y nuevo mundo (Madrid: viuda de Alonso Martin, 1625), 184r-v. 
dispersion over a global network of administrators and correspondents who share their information with the monarch and his close collaborators by means of paper reports circulated via a sophisticated postal system, on the other. ${ }^{15}$

As a versatile, disposable, light and highly mobile medium, paper provided the administrative scaffolding for social, economic and political structures. It was instrumental in sparking a revolution in communications which opened the way to a new age of information towards the end of the Middle Ages. What is more, it held the power to become the representational double of the world itself. It created a host of armchair travellers thanks to the proliferation of inexpensive travel literature profusely illustrated with maps: cartography became a documentary genre of the highest order during the age of exploration. Last, but not least, the bureaucrat monarch and the armchair traveller found their financial and economic counterpart in merchant bankers who ran their business from their desks thanks to a global network of correspondents. ${ }^{16}$

\section{Finance and Trade}

Jost Amman's broadside The Allegory of Trade is a large, single-sheet engraving (30" $\mathrm{x}$ 46 ", or $76.2 \mathrm{~cm} \times 116.84 \mathrm{~cm}$ ) consisting of six different woodcuts produced around 1585 to celebrate the practice of trade, and Antwerp in particular as one of its most important centres. Amman presents a complex composition that displays the geographical spaces of trade, lists its most important hubs, and illustrates the diverse offices and agents involved in it. An allegory of Fortune stands as one of its main protagonists on the symmetrical axis of the engraving, giving it a visual sense of order and harmony in paradoxical contrast to the presence of the fickle goddess. Fortune appears flanked by two great books resting on the arms of a balance with a crowned figure as an allegory of justice ('Iudex') in the middle, all of which is held directly above the head of the goddess by Mercury. The books are identified as 'creditor' and 'debitor:' As tokens for the balance of trade, they are part of the flow of value that circulates throughout the entire trade system.

15 On early postal systems, see BEHRINGER, 'Communications Revolutions.' Relevant primary sources include GIOvanni DA L'Herba and ChERubinus DA STElla's Itinerario delle poste per diverse parte del mondo (Rome: Valerio Dorico, 1563) and OTTAVIO COTOGNO's Nuovo itinerario delle poste per tutto il mondo (Venice: Lucio Spineda, 1611; Giacomo Zatonni, 1616). Recent projects on early modern private postal companies also include The Brienne Collection Project, http://brienne.org/. Vander Hammen y León emphasises how Philip II always carried a portable archive with him and praises his extraordinary capacity to deal with paperwork in a record time (VANDER HAMMEN Y LEÓN, Don Filipe, 186 v). Another of Philip II's first historians, Luis Cabrera de Córdoba, described him as 'el rey papelero,' who had the power to move the world with his pen and his papers, LuIS CABRERA DE CÓRDOBA, Historia de Felipe II: Rey de España, vol. 1, eds José Martínez Millan and Carlos Javier De Carlos Morales (Salamanca: Junta de Castilla y León, 1998), 368. On Philip II's bureaucratism and his actuarial habits, see Arndt Brendecke, Imperio e información. Funciones del saber en el dominio colonial español ([Imperium und Empirie. Funktionen des Wissens in der spanischen Kolonialherrschaft, 2009], trans. Griselda Mársico (Madrid and Frankfurt: Iberoamericana \& Vervuert, 2012), chapter 1.

${ }^{16}$ See MüLLER, White Magic, 42 on this, and above all chapter 3, $201 \mathrm{ff}$. 


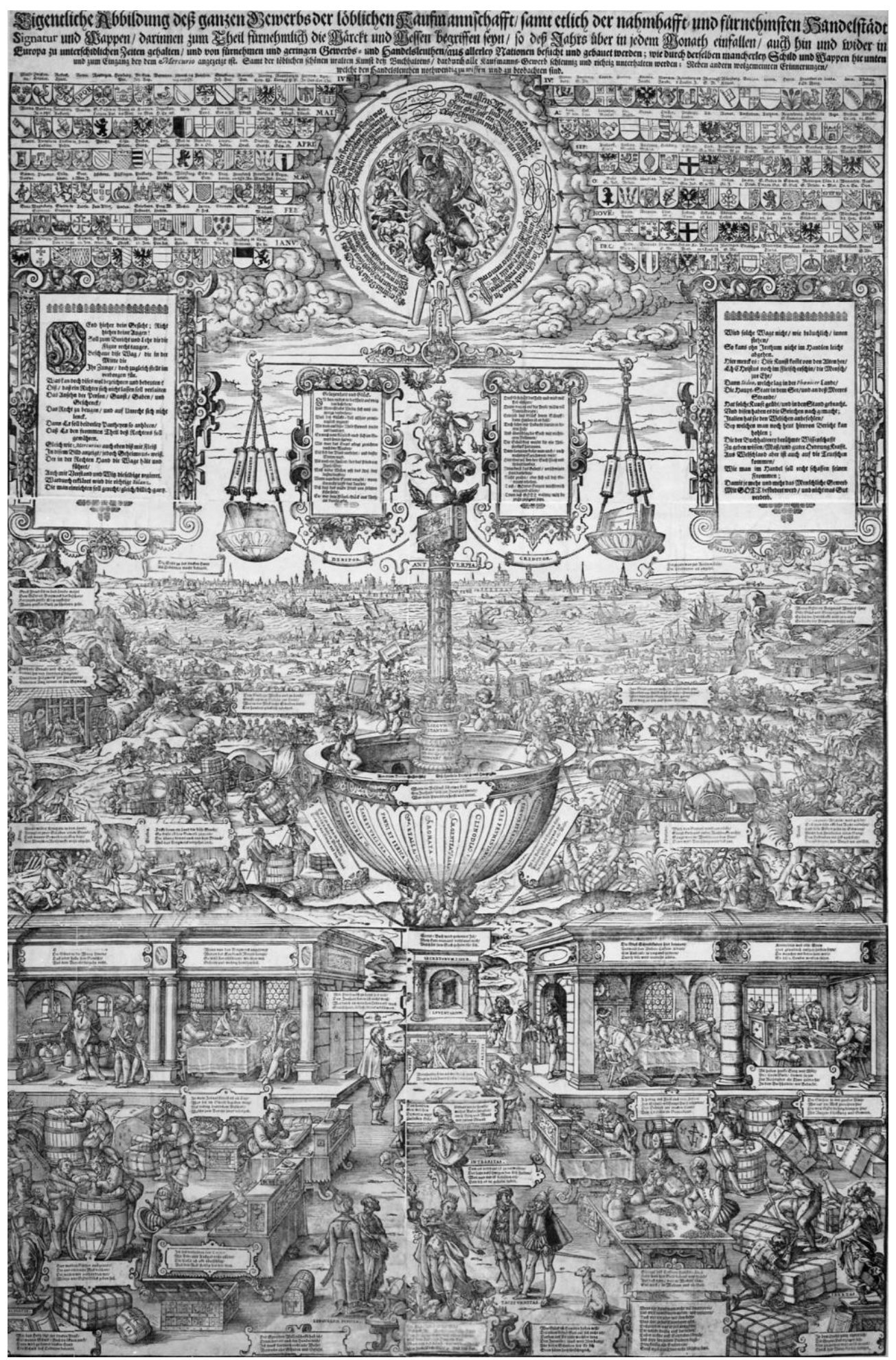

Figure 5. Jost Amman, Allegorie van de handel (The Allegory of Trade), 1585 (1800-1854, late impression), copy at British Museum, (C) The Trustees of the British Museum, reproduced under Creative Commons Attribution-NonCommercial-ShareAlike 4.0 International (CC BY-NC-SA 4.0) license. A high-definition reproduction is also available at Museum PlantinMoretus, https:/ /www.museumplantinmoretus.be/nl/pagina/allegorie-van-de-handel. 
In spite of its iconic harmony, the balance reveals its precarious equilibrium by hovering in mid-air above Fortune, who stands on a winged sphere - a conventional component in her allegorical representations. The sphere in turn rests on a third book marked as the 'zornal,' the log used to register the daily flow of data between creditors and debtors, symbolised by the chains that connect the three books. The diary then stands on top of a column, which rises from a fountain inscribed with a range of different tradeable materials and goods.

This complex architecture with Fortuna, the balance, the column, the fountain and the three books - of creditors, of debtors and the diary - plus the goods and products, all rest upon an urn inside which there is a fourth book, the inventarium. The entire architecture and balance of trade thus appear articulated by the information that flows through these four different manuscript books: of creditors, of debtors, the diary and the inventory.

At the foot of the column sits another central figure: the chief merchant handing over a letter to a messenger. He appears surrounded by several secretaries, clerks and accountants, all of them busy exchanging currency and duly registering all the information concerning business in letters and logbooks. Their desks are richly decorated, well furnished with all the tools of a scribe and surrounded by numerous chests filled with moneybags. Standing next to one of them are two men dressed in Turkish attire over the legend 'linguarum peritia,' to stress the fundamental role of translators and interpreters in the exchange of information in international trade. The background on the upper half of the engraving is populated with ships carrying their cargo all over the world, connecting the different cities represented by their coats of arms and the dates of their respective trade fairs. Underneath them we find stevedores busy at work, loading and collecting the traded goods.

Amman successfully portrays the inherently mobile nature of trade, with its material goods always on the go, and the use of the variety of paper formats to register, coordinate, control and share the numbers, data, weights and measures. The engraving amounts to a celebration of material transport and immaterial (or quasi immaterial) communication as the logistics that make trade possible, within which paper played a central role as a material repository of information.

For Philip II at his desk in El Escorial, or hard at work in his travelling archive, or for the readers of illustrated travel literature in their studios, semiotically charged paper stood for the world, or rather, for the many new worlds in the expanding globe that was coming under the ken of sixteenth-century Europe: the administrative realms of an emperor, or the geography and chronographic outlines of the world with its exotic regions and peoples. If maps were representations of the world on parchment and paper, which gave armchair travellers the opportunity to sail the globe from the safety of their homes, in the case of mercantile and financial documents paper constitutes a textual space where figures, tables, graphics and other symbolic systems 
register the transactions that take place in the actual physical world of trade, which the merchants could then trace and control from their desks.

The importance of a merchant's paper-based records is demonstrated by $\mathrm{Il}$ Negotiante (Genoa: Pietro Giovanni Calenzani, 1638). A practical handbook on business and finance penned by Domenico Peri (1590-1666), Il Negotiante is in important aspects the textual counterpart to Amman's iconic allegory of trade. Some of its opening chapters are devoted to the protocols employed in the elaboration of mercantile and financial documents, their management and classification. ${ }^{17}$ Chapter 10 deals with the 'scritturale, the officer whose job is to register all the information concerning the activities of the company, and whose office is according to Peri the most important among all of those required for the good governance of business. ${ }^{18}$ In chapter 12 ('De contratti'), Peri provides a definition of the contract which takes us back to Gerson, reminding us of the similarities between the contract and currency, and of what both have in common as documentary genres whose performative value is sanctioned by formal semiotic protocols, their consensual nature, and their legitimation and enforcement by a central authority. ${ }^{19}$

The role of paper documents in the conduct of international trade constitutes an important aspect in the complex relations between paper and power. It was, as I have already mentioned, an important part of the macro-economic and complex administrative structures that were created as a result of the gradual expansion of trade and finance on a global scale. It also played a fundamental role in the creation and administrative upkeep of the modern state. And it was also fundamental when it came to the transmission and generation of information and knowledge in disciplines like trigonometry, astronomy and cartography, all of which were essential for the establishment of paths for imperial expansion through exploration and conquest, the latter in turn depending for its management on a sophisticated paper-based bureaucratic machine. In short, we can talk about a heterogeneous and open-ended, but nevertheless circular structure that facilitated the emergence of a new era of state administration by way of paper, alongside a new age of paper money and paper-based financial exchanges, which in turn constituted the lifeblood of global trade and the imperial body politic.

Paper was the medium employed in the codification and exchange of value through letters of exchange and letters of credit, and as such it played a fundamental role in the gradual dematerialisation of the global economy. This was part of a shift

\footnotetext{
${ }^{17}$ Chapter 3 deals with the basics of script ('Dello scriuere,' 21-27), chapter 4 with basic mathematical operations ('Dell'Abaco,' 28-31). Chapters 5 and 6 concern the formats and protocols of the different genres of documents required in the practice of trade (5, 'Del modo di scriuere lettere, ordini e commissioni,' 32-39; 6, 'Della scrittura mercantile,' 40-58), including some useful samples of formats and forms to be used in account books.

18 'Dello Scritturale,' 78-85.

${ }^{19}$ Chapter 12, 'De contratti,' 97-100. The rest of the book contains models of letters, which also makes it a catalogue of protocols, and common rhetorical and legal practices in trade and finance, all of which are techniques to store, classify, retrieve, and share data and information.
} 
from the use of precious metals as tokens for the circulation of monetary value and their exchange for goods to the use of more complex financial instruments and the eventual emergence of paper currency - a new development which, as we shall see, was found objectionable by some.

The development of paper money and paper credit in Europe was preceded by the use of paper money in China in the tenth century. There was also a medieval Islamic paper economy, which saw practices in Cairo like cashless orders of payment and purchases on credit. The Abbasid Caliphate also saw the creation and use of bills of exchange. ${ }^{20}$ Europeans first heard about paper money in the Far East, well beyond the familiar region of the Levant, from Marco Polo, who provided his readers with a detailed description first of the material nature of paper money, processed from the bark of mulberry trees, and then an account of its conversion into a carrier of financial value, by means of its inscription, authentication with official seals, and its ultimate legitimisation and enforcement as an exchangeable form of currency by the central authority of the Great Khan. ${ }^{21}$ In his De moneta, Oresme described coins as semiotic instruments articulated upon formal protocols whose consensual value and circulation was sanctioned and enforced by an authority, usually a monarch, as well as by the (supposedly) immanent material value of the precious metal used as the medium.

The virtual relations established by the data registered and shared by means of letters of credit and bills of exchange, and the value recorded in inventories and logbooks, all contributed to the creation of capital, which thus emerged from a cypher in motion and semiotic systems in circulation, rather than from the hard metal of gold, silver or copper coins. Modern capitalism arose from the account books that registered creditors and debtors, the inventories and logbooks that recorded what came in and what went out, and the abstract (but nevertheless exchangeable) credit which emanated from the semiotics of financial and mercantile contracts. The result was that these increasingly abstract practices of merchant banking created alternative documentary genres for the representation, circulation and generation of financial value which frequently escaped the control of the monarch and became totally detached from the material value of the medium that carried it. ${ }^{22}$

\footnotetext{
${ }^{20}$ Shelomo Dov Goitein, A Mediterranean Society: The Jemish Communities of the Arab World as Portrayed in the Documents of the Cairo Geniza, vol. I, Economic Foundations (Berkeley, CA: University of California Press, 1999), 240 ff. On Arab paper, see KARABACEK's classic Arab Paper. [Das Arabische Papier, Vienna, 1887], trans. Don Baker and Suzy Dittmar (London: Archetype Publications, 2001), and more recently Jonathan Bloom, Paper Before Print: The History and Impact of Paper in the Islamic World (New Haven, CT: Yale University Press, 2001).

${ }^{21}$ Chapter 18, second book, 'Della sorte della moneta, di carta, che fa fare il Gran Can, qual corre per tutto il suo dominio,' in GIOVAnNi BATTISTA RAmUSIO, Secondo volume delle nanigationi et viaggi (Venice: Giunti, 1583), 29r.

22 As Elvira Vilches suggests 'the new dematerialized bank credit did not entail deferred payments but rather functioned as a promise to pay (IOU) issued outside the authority and control of the sovereign's mint,' ElviRA VILCHeS, New World Gold: Cultural Anxiety and Monetary Disorder in Early Modern Spain (Chicago, IL and London: University of Chicago Press, 2010), 7.
} 
The power of the abstractions generated by early modern banking made themselves felt even for rulers as powerful as Philip II. Whereas with his pen and his papers, and his army of archivists, clerks, ambassadors and messengers, Philip II could create and sustain an administrative network that carried significant political weight, his finances were controlled by Genoese and German bankers who used paper as a material signifier to generate, circulate and hoard an enormous amount of value which came to represent an alternative empire of financial paper.

The perception of paper as a repository of financial and economic value with enough power to bring about the default of an entire kingdom certainly did raise many eyebrows. The Spanish arbitrista González de Cellorigo blamed the bankruptcy of the Hispanic monarchy in 1600 on the paradox that, in spite of all the territorial and material value of the kingdoms, its wealth had all gone up in the 'air, in papers, contracts, census and letters of exchange.' For Cellorigo, Ariosto's allegory of Discord had transmuted into the confusing alchemy of financial paper that ailed the Hispanic kingdoms. ${ }^{23}$

There is a telling analogy between Cellorigo's outcry and current complaints about the uncoupling of the financial economy from the real economy, now that our troubles do not stem from paper money or paper credit, that is, value that circulates in very light, hardly tangible matter. Today money and financial value circulate in an even more intangible medium, in electronically generated signifiers which have the potential to deal with a huge mass of information - and hence the financial value it represents - at amazing speed and across immense distances. Many of these operations appear, besides, to be managed not by individuals, but by algorithms which are based on their remote ancestors, the libri d'abbaco and arithmetic handbooks employed by early modern merchants and bankers. We have gone a long way indeed from Peri's chapters on script and the abacus, Amman's papers, translators and scribes, to globally interconnected computer programs and databases run by algorithms. The media and the technologies are certainly different, above all as regards their power, speed and scope, but the core principles and processes remain similar: the registration, storage and communication of economic and financial information on a light, fast and supple medium which is then run by mathematical principles and an oligarchy of expert operators.

But well before electronic media, the combination of paper, script and arithmetic - that is, a new medium and two different semiotic systems - were enough to bring about the dematerialisation of the economy, and to set in motion the increasing abstraction of commercial and financial exchanges established by the terms of a contract. $^{24}$ That abstract paper money was perceived as related to the consensualcontractual culture of this period is demonstrated by Oresme's definition of coins, and by Peri's definition of the contract as 'un consenso reciproco di molti, ò almeno di due persone, la queli conuengono insieme sopra qualche cosa, per il consentimento legitimo de'quali risulta in ambe, ò il

23 Martín González de Cellorigo, Memorial de la política necesaria y útil restauración a la República de España (Valladolid: Juan del Bostillo, 1600), 29.

24 VILCHES, New World Gold, 6-7. 
alcuna delle parti qualche obligatione. ${ }^{25}$ González de Cellorigo does accept this definition, but complains that paper money is now used for other purposes, different from those for which it had been legitimately created, that is, exclusively within contractual mercantile exchanges, not outside them, and certainly not to generate abstract money or credit. Money, he proclaims, is the cause of the exchange, not the result of it. Cellorigo misses the tangibility not just of gold and silver, but of goods themselves. He argues that in the exchange of manufactured and raw materials ('cosas naturales e industriales') for American gold and silver, Spain neglects not just the production of these goods, but also disregards the material value of precious metals and only reaps the credit money that emanates from financial contractual exchanges. This abominable abstraction, he concludes, is the ultimate cause of the economic decline of the country. ${ }^{26}$

About two hundred years after Cellorigo, Goethe saw paper money as an evil invention which he attributed to Mephistopheles, turning the beginning of the second part of his Faust into a critique of immaterial fiat money. ${ }^{27} \mathrm{~A}$ few years later, in his history of the French Revolution Thomas Carlyle would echo Goethe's words on paper money, and on paper in general, in a description of the deceitfully peaceful years that led to the opening of the Estates General by Louis XVI and the subsequent Revolution as the Age of Paper. ${ }^{28}$

\section{Information and Knowledge}

L'écriture hors livre répond à l'agriculture hors sol, à l'économie des immatériaux, aux échanges monétaires sans espèces.

REGIS DEBRAY, 'Dématérialisation et désacralisation' 29

Complaints about paper money and abstract finance as abominations punctuate the longue durée of intellectual and economic history. In the present day, these grievances have translated into the current outcry against financial capitalism, its digital algorithms and complex market arcana - warrants, options, derivatives, and so on, which only an elite of initiates can understand, generate and control. Like in finance and currency, the abstraction of immaterial or quasi immaterial media arouses fear and enthusiasm in equal measure, in the realms of information and knowledge too.

New media have always excited the imagination of those who see in them the potential to liberate, universalise and potentially democratise knowledge. The advent of the Internet about three decades ago brought about what appeared to be a process of

\footnotetext{
25 PERI, Il Negotiante, 97, italics in the original.

${ }^{26}$ GonZÁlez de Cellorigo, Memorial, 22.

27 Marc Shell, 'Money and the Mind: The Economics of Translation in Goethe's Faust,' Modern Language Notes, 95, no. 3 (1980): 516-62, see 534-35.

28 Thomas Carlyle, The French Revolution: A History, 2 vols., vol. 1, The Bastille, 3rd ed. (London: Chapman and Hall, 1848), 37.

${ }^{29}$ REgIS DeBRAY, 'Dématérialisation et désacralisation: le livre comme objet symbolique,' Le Débat 86, no. 4 (1995): 14-21, see 19.
} 
decentralisation and the release of information and knowledge production from the elites who had controlled it hitherto. In the new medium, many saw the potential to turn the monologue of books into a digital, free-floating global conversation, and to turn readers from passive recipients into active agents who could not just interact with the text but even intervene upon its configuration. Already in 1995, amongst the enthusiasm of those who saw the World Wide Web as the electronic space for a global community of free agents, Régis Debray was cautiously ambivalent and ultimately sceptical about these new possibilities. The materiality of the book-object, he claimed, over the course of centuries - indeed over millennia - had acquired an aura that had elicited veneration in the realms of spirituality and knowledge, from the Bible to the last printed encyclopaedias of the twentieth century, on the part of a multitude of different communities. This aura, he concluded, resulted from a sort of material-mediatic coherence. ${ }^{30}$ But once the fetishistic value of the book-object, with its remarkable power to energise and rally the emotions and identities of communities of all sorts, vanishes within the electronic dream of an immaterial and supposedly egalitarian global village, Debray foresaw a return to the most atavistic variety of materialities: a revalorisation of the earth, wood and stone, and all the primaeval values they tend to stand for. About ten years later, in his critical approach to new digital formats and the potential they display for the creation of a universal online library under the auspices of digital corporations like Google, with the eloquent question that stands as the subtitle for his book, La grande numérisation, Y a-t-il une pensée après le papier?, the historian of paper Lucien X. Polastron expressed his reservations about such projects as potentially dystopian totalitarian nightmares.

These apocalyptic approaches contrast with the optimism raised by a different sort of medium which prompted two early twentieth-century proposals. The first of them was H.G. Wells' World Brain (1938), the name he gave to his scheme for a global encyclopaedia. He saw it as a feasible plan based on the potential of a new medium that had just been made available around the time he was campaigning for his ambitious scheme in a series of lectures and publications. It was, of course, not paper (which was old hat), nor the digital format (which was yet to come): Wells's World Brain would be registered on microfilm. ${ }^{31}$ The bibliographer and information scientist Paul Otlet (18681944) also saw great possibilities in microfilm and other new early electronic media. Wells' contemporary and acquaintance, and a fellow optimist believer in progress, Otlet outlined plans first for what he called an archivium of humanity and a universal bibliography which would function as its catalogue. This would then lead to a universal microfilm library, an institution which he called the Mundaneum or City of Knowledge. The faith in new technologies led him to suggest a number of new media and methods that could be used to achieve what he encapsulated in a slogan as a new type of 'universal

30 DEBRAY, 'Dématérialisation et désacralisation,' 16.

31 W. BOYD RAYWARD, 'H. G. Wells's Idea of a World Brain: A Critical Reassessment,' Journal of the American Society for Information Science 50, no. 7 (1999): 557-73, see 563-64. 
civilisation, universalist education. ${ }^{32}$ This would be made possible by a host of 'mechanical instruments' that would work as the 'extension of the word and the book. ${ }^{33}$ However, as a bookish and earnest young man, well before he embraced the possibilities of new electronic and photographic information technologies, Otlet resorted to a more traditional and time-honoured method to annotate and classify information, a process which he recorded in his pen-and-paper diary:

In taking notes from authors one has the incontestable advantage of making a compendium; that is to say, a small abridged treatise which contains useful passages for one's own particular use... To gain time, instead of immediately developing a thought that one has read, one simply makes a note of it on a piece of paper which is put in a folder. On Saturday, for example, these papers can be taken up one by one for classification and also for development if this is necessary... Rather than classifying the loose leaves of the same format each week, one can write all the subjects in the same exercise book, taking care to give a whole page and its verso to each new subject. Once the notebook is filled, the leaves can be torn out and classified. However, lots of things are difficult to classify and these one gathers together ad hoc in a notebook without recopying them. ${ }^{34}$

Wells and Otlet were enthusiastic about the possibilities of new electronic media at the dawn of an era that only now is starting to see some of their ambitions realised. But before these were available, they used paper to register and classify information in exactly the same way in which European scholars had done for centuries. For more than 700 years before the age of electronic media, paper was unbeatable as a means of communication and as a modular repository of information. Lisa Gitelman stresses the epistemic power that paper-based documents have held for centuries: to the extent that "information is understood today to come in discrete "morsels" or bits partly because of the way the concept of information reifies the properties of paper documents; they are separate and separable, bounded and distinct. ${ }^{35}$

These modular epistemic units could then be incorporated as building blocks into a larger, discursive or narrative whole - be it in science, history, a court case, a catalogue, a memorandum or a report. The information and knowledge recorded on these manuscript pieces of paper could be copied, reproduced, recorded and recombined in as many different ways as necessary. Some of these formats have reached us in the form of commonplace books, composite manuscripts, provisional catalogues and inventories

\footnotetext{
32 W. BOYD RAYWARD, The Universe of Information: The Work of Paul Otlet for Documentation and International Organisation (Moscow: VINITI for the International Federation for Documentation, 1975), 295, http://hdl.handle.net/2142/651.

${ }^{33}$ BOYD RAYWARD, The Universe of Information, my emphasis.

${ }^{34}$ Quoted in BOYD RAYWARD, The Universe of Information, 17.

35 Gitelman, Paper Knowledge, 4; GeOfFrey Nunberg, 'Farewell to the Information Age,' in The Future of the Book, ed. GEOFFrey NunBerg (Berkeley, CA: University of California Press, 1996), 103-38, see 120. On the use of paper slips, see ANN BLAIR, Too Much to Know: Managing Scholarly Information before the Modern Age (New Haven, CT and London: Yale University Press, 2010), 210-27. Medical recipes were among the practical uses for paper slips: the Archivo de la Real Chancillería de Valladolid preserves over 200 of them, the so-called Recetas de Manzanedo, which date from the sixteenth century, https://www.culturaydeporte.gob.es/cultura/areas/archivos/mc/archivos/acv/actividades/docdestacados/recetas/presentacion.html.
} 
- heterogeneous collections of notes on paper of different sizes which scientists and scholars used as rough sources for their more articulated and complex end products.

All of this demonstrates the need to reassess traditional interpretations of the significance of print over and above paper in the scientific revolution and in intellectual history in general. And so we should direct our attention also to paper and the changes it brought about not just in administration and finance, but in science and the humanities too, as well as its early contribution to the redefinition of disciplines of knowledge from the twelfth century up to Gutenberg's invention, and thereafter, in close alliance with print. Print was without any doubt a ground-breaking new technology, but it took off in the spectacular way it did thanks to the fact that there was a pre-existent medium that could be used as the vehicle to launch new formats - bound-printed, unbound-printed - that were destined to change the world of knowledge forever.

Recent statistical surveys demonstrate that well before the invention of print the production of the manuscript-bound book format had already increased significantly thanks to paper. The widespread use of paper in new educational institutions like universities and more traditional centres of textual production like monasteries dynamised the drive towards a gradual standardisation and universalisation of knowledge, which thus laid the ground for the acceleration of this process after the arrival of the printing press. When compared with the explosion in book production brought about by print, the previous figures are certainly modest, but they are still very significant in contrast to the period that preceded the arrival of paper in Europe. ${ }^{36}$

Paper stands in a paradoxical position, as not totally immaterial, but still facilitating long-term processes of abstraction in a large variety of disciplines of knowledge and human practices. Paper, says Lisa Gilman, is familiarly the arena of clarity and literalism - of things in black and white - at the same time that it is the essential enabler of abstraction and theory, as in mathematics and theoretical physics.' As demonstrated by Debray and Polastron, the dematerialisation of information and knowledge has deprived us of a tangible medium which could stand for the contents it registered and for human cognition: paper, to borrow Wells' expression, could be taken to be the material manifestation of the human mind at work, the contents it could hoard and the information it could process. As a blank page, paper can even turn into an icon for nothingness and absence. With electronic media we have gone a step further, for digital bits are nowhere to be seen other than in their indirect and ephemeral on-screen manifestations.

The notion of paper as a trope that denotes all that is external to the mind, either in isolation or in conversation with other minds, is coextensive with the idea that any medium, by facilitating the registration of information and knowledge which are apprehended and

36 See the statistics provided by UwE NEDDERMEYER's Von der Handschrift zum Gedruckten Buch: Schriftlichkeit und Leseinteresse im Mittelalter und in der frühen Neuzeit, quantitative und qualitative Aspekte, 2 vols. (Wiesbaden: Harrassowitz, 1998); see also DANIEL HobBINS, Authorship and Publicity before Print: Jean Gerson and the Transformation of Late Medieval Learning (Philadelphia, PA: University of Pennsylvania Press, 2013), 7-9. 
elaborated by human cognition, can turn into its mirror. This idea was of course employed by Wells in his own trope of the World Brain to describe his universal repository of knowledge. Projects for universal archives and libraries tend to be tied to grand teleological schemes. That was the case of Hernando Colón (1488-1539), son of the explorer Columbus, who intended to gather all books ever published, in all languages, and all possible formats, and to compile a series of catalogues that would summarise their contents. Hernando put his collection and his catalogues to the service of Charles V's concept of universitas christiana, as an empire of knowledge to emulate the territorial empire that his own father had bestowed upon the Castilian crown. This was an idea which Hernando proudly proclaimed in the coat of arms he designed for his tombstone.

The castle and the lion which symbolise the kingdoms of Castile and León appear alongside a cartography of islands in the middle of the ocean, with the orb and cross that represent imperial sovereignty. The entire ensemble is surrounded by the four main catalogues elaborated by Hernando, the discursive counterparts to the iconic cartography that symbolises his father's conquests. ${ }^{37}$ The first three of these catalogues would respectively classify his titles into disciplines, subject matter and authors, whereas the fourth one would consist of a series of summaries or epitomes with the contents of every book ever published. The books themselves, however, were not to be shared: they would remain ensconced in his library in Seville as a private universal repository of knowledge, to be used only in case of extreme necessity when a particular title could not be found elsewhere. The four catalogues, on the other hand, were to be copied and distributed across the globe so that readers could navigate this new world of knowledge. ${ }^{38}$ After Hernando's death, his secretary Juan Pérez left a memorandum that describes the nature and function of each of these catalogues, and the principles that guided their compilation, including a practical example of the use of paper as the repository for modular information which could then be arranged and rearranged as many times, and in as many different ways, as would be convenient:

There are besides in the library some slips of paper strung together, which go almost from the first book in the library to a little over ten thousand, although in between some are missing and there are some others beyond ten thousand; we call these annotations and they were to be used to compose the table of the sciences and authors, to know how many authors have written about which sciences. ${ }^{39}$

\footnotetext{
${ }^{37}$ The original copy of Hernando's last will and testament is in the Archivo Provincial de Sevilla, Oficio V. Escribanía de Pedro de Castellanos. Legajo $4^{\circ}$ de 1539, Folio 287. The design for his tombstone is in fol. 290r.

${ }^{38} \mathrm{On}$ the relation between the worlds of knowledge production and circulation, and that of finance and trade, see chapter 2, 'Trade Secrets,' in José MARÍA PÉREZ FERnÁndEZ and EDWARD Wilson-LEe, Hernando Colón's New World of Books. Toward a Cartography of Knowledge (New Haven, CT and London: Yale University Press, forthcoming 2021), 55-96.

39 JuAn Perez, 'Memoria de las Obras y Libros de don Hernando Colón,' trans. Pérez Fernández and Wilson-Lee, in Hernando Colón, eds PÉREZ FERnÁndeZ and WiLSON-LEE, 201. In another of his provisional catalogues, the so-called Registrum $A$, we can see several practical cases of the use of paper slips to dynamise and register information in a catalogue as it was being put together, HERNANDO COLÓN [Memorial de los libros naufragados o Registro antiguo o Registrum A], February-November 1521, Biblioteca Capitular y Colombina, sig. 10-1-15. See for instance, fols. 44v-45r, 48 v-49r, et passim.
} 


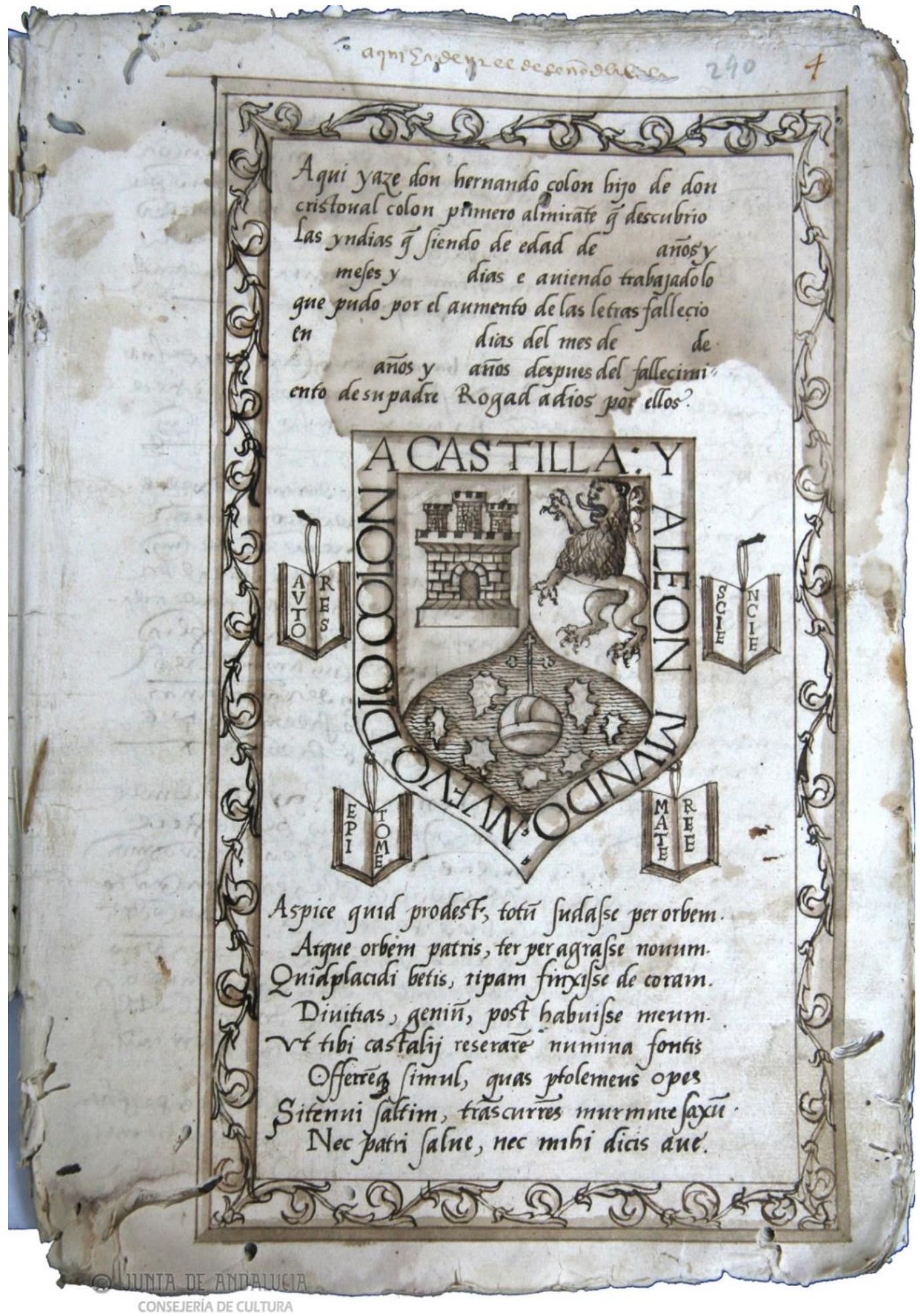

Figure 6. Hernando Colón's coat of arms, in his own design for his tombstone. Reproduced with permission from the Archivo Histórico Provincial de Sevilla. 
As the head pilot (piloto mayor) at the Casa de Contratacion, Hernando was familiar with the management of an enormous amount of paper documents bearing information sent in by pilots, astronomers and cosmographers from the four corners of the world. In 1526 Emperor Charles V charged him with the task of gathering a team of experts in the recently created institution. He was ordered to collect and coordinate information with a view to the creation of a universal mappamundi, the so-called Padrón Real, which was to become the blueprint for all other maps used by pilots around the globe. ${ }^{40}$ The imperial decree demonstrates the challenge that exploration and imperial expansion posed for Charles $\mathrm{V}$ and his administrators. The maintenance and defence of such a vast empire did not just require able soldiers and sailors, astronomers, mathematicians and cosmographers. Expert information and knowledge engineers were also essential: officers capable of collecting, sorting out and classifying huge amounts of data, and then processing all this unprecedentedly vast amount of information into other documents that would make sense of the world and help imperial officers conduct their business.

Like all such grand schemes, Hernando's utopian library and cataloguing systems never fully materialised, but the universalist impulses of the global monarchy he served kept pushing for other projects led by similar principles. We have already mentioned Philip II's archive in Simancas as an administrative mirror, a paper double, of his geographical empire. But like Hernando, the monarch also had plans for a comprehensive library and other collections, which stresses the relation between paper and the practices of cataloguing, as well as the administration of book and artefact collecting. Some of the ideas behind it appear in Juan Páez De Castro's Memorial a Felipe II sobre la utilidad de juntar una buena biblioteca (1555), which is part of a manuscript sammelband still deposited at the library which the monarch actually created in El Escorial. ${ }^{41}$ De Castro's plan also includes the design for the three different spaces where the collections were to be deposited. The first of them would be used for books, with an emphasis on Scripture, the Church Fathers, theology, law and philosophy. The second one was to be devoted to maps, globes, but also to watches, astrolabes and other scientific instruments used for the disciplines of astronomy and mathematics, alongside rare antiquities, and botanical and zoological samples brought from all over the territories under the jurisdiction of the monarch. Royal officers in the Americas were instructed to send rare objects, and the Hispanic monarchy, as we shall see, set up a grand programme to collect information from the different territories of its global empire. Last, the third space would work as an archive, very similar in contents and function to Vander Hammen's description of the archive in Simancas.

The sammelband with de Castro's memorandum is relevant in its own right, since it also includes other documents that sample the methods and categories employed for

40 Archivo General de Indias, Indiferente 421, vol. 11, fol. 234r; trans. Pérez Fernández and Wilson-Lee, Hernando Colón, 243-44, q.v., for more details on Hernando's role in the Casa de la Contratación, and the relation between this cartographic project and his library.

${ }^{41}$ Real Biblioteca del Monasterio de El Escorial (BME), Ms. \&. II. 15, 192v-194v. JUAN PÁEZ DE CASTRO, Memoria a Felipe II sobre la utilidad de juntar una buena biblioteca, ed. GONZALO SANTONJA, prologue Gregorio SALVAdOR (Valladolid: Junta de Castilla y León, 2003). 
the collection of information. It contains a very practical and down-to-earth memorandum on the price of manuscripts, alongside mixed repertories of books and items of a different nature (books and paper documents, books and coins, and books and relics). The sammelband constitutes, in short, an inventory of different documentary genres, which reminds us that information, and the practices of collecting and classification, concerned not just paper-based semiotic artefacts, but that this medium was just one of a large variety of other sorts of symbolically charged, documentary objects of significant value and performative power. Since the index lists other catalogues, it is also a meta-register of sorts which can be used to search for repertories of the items that eventually went into the making of Philip II's larger collections at El Escorial.

Imperial administration relied on practices of transcultural communication and interpretation, since the information sent from distant and exotic territories had to be culturally translated in terms that the administrators back in the Iberian peninsula could first understand, and then put to practical use. It also called for common protocols and standard questionnaires, as well as a team of administrators, scribes and archivists, with notaries to certify the veracity of the information. ${ }^{42}$ Arndt Brendecke stresses that the memoriales or provisional reports produced by these clerks were only a guide or a memory aid for actual oral exchanges, and that the information recorded in them would normally be discarded and destroyed after being discussed, used and incorporated into more permanent registers.

Manuscript AM 253 fol. at the Arnamagnæan Collection in Copenhagen constitutes an excellent example of the use of paper slips as disposable modular units for the management of knowledge during the middle stages of the production of more complex and permanent documentary artefacts - which most of the time consisted of books, but could also be long, reasoned and discursively articulated reports or memorandums in any discipline whatsoever. This particular composite manuscript belonged to Pedro Chacón (1526-81), a Spanish Hellenist and mathematician who held a chair at the University of Salamanca until he was called to Rome by Pope Gregory XIII to work as part of the team charged with the reform of the Julian Calendar. ${ }^{43}$

\footnotetext{
42 The royal decree that set in motion these plans for the global collection of information established 'very detailed rules on implementation [which] regulated how the collections of data and descriptions for individual subfields were to be carried out' (Brendecke, Imperio e información, 189). For samples of these questionnaires, see Francisco DE SOLANO and PILAR PONCE LEIVA, eds, Cuestionarios para la formación de las relaciones geográficas de Indias: Siglos XVI/XIX (Madrid: CSIC, 1988).

${ }^{43} \mathrm{On}$ this and other Hispanic manuscripts at the Arnamagnaan Institute, see N. KIVILCIM YAVUZ's 'Notes from the Sixteenth Century: AM 828 4to,' Amamagnaean Institute Manuscript of the Month, October 15, 2018, https://manuscript.ku.dk/motm/notes-from-the-sixteenth-century/; as well as her 'Judging a Book by its Cover: Manuscripts with Limp Bindings in the Arnamagnaan Collection,' in From Text to Artefact: Studies in Honour of Anne Mette Hansen, eds KATARZYNA KAPITAN, BEEKE STEGMANN and SEÁN VRIELAND (Leeds: Kismet Press, 2019), 121-40. I am grateful to the Arnamagnaan Institute not just for the images, and the permission to reproduce them, but also for facilitating my access to the volumes. I must also thank Prof. Matthew Driscoll for bringing these manuscripts to my attention, and providing relevant information about them.
} 
JosÉ MARÍA PÉREZ FERNÁNDEZ

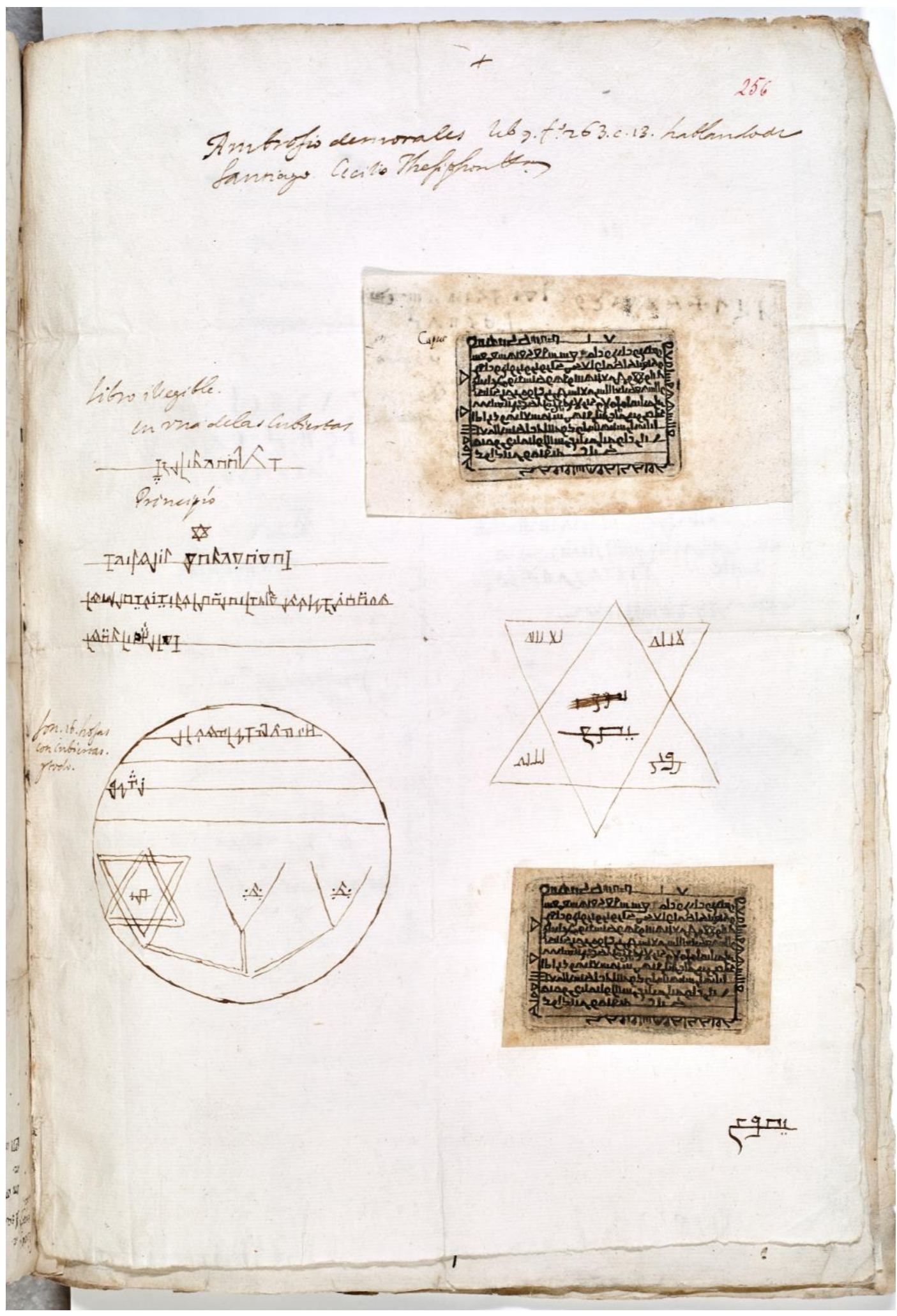

Figure 7. Copenhagen, Arnamagnæan Collection, AM 253 fol., f. 256r. Photo: Suzanne Reitz. Used with permission. 


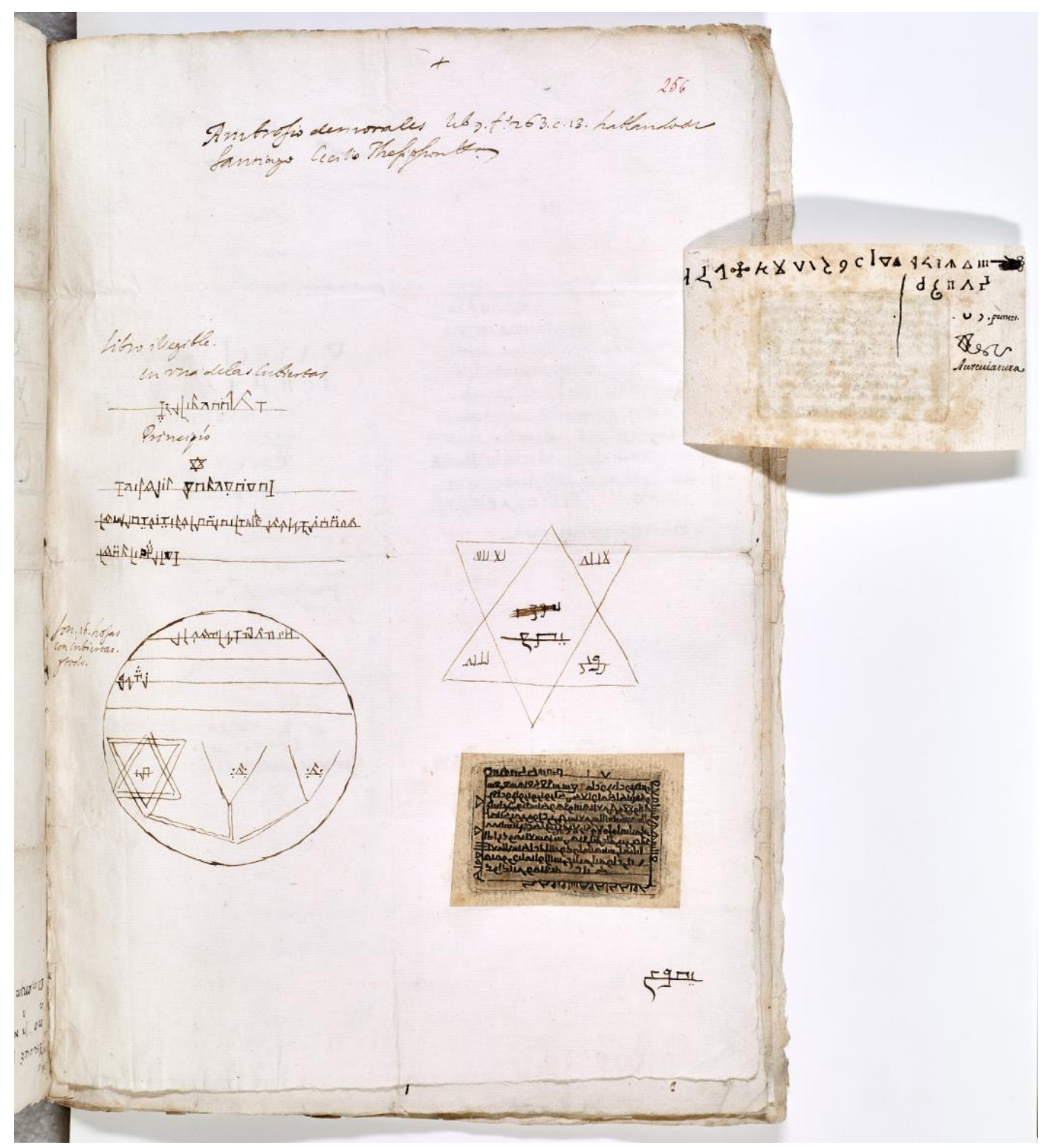

Figure 8. The verso of the paper rectangle pasted on the upper half of AM 253 fol., fol. 256r. Copenhagen, Arnamagnæan Collection. Photo: Suzanne Reitz. Used with permission.

This sammelband was put together by Chacón himself in Rome, where he presented it to a close friend, Luis de Castilla. From the hands of de Castilla, the manuscript passed on to the library of the Count-Duke of Olivares in Seville. It was subsequently purchased by the Danish ambassador and collector Cornelius Lerche, who took it with him to his country. From Lerche's library the manuscript was transferred in 1681 to the collection of another collector and scholar, Árni Magnússon, who bequeathed his books and documents to the University of Copenhagen, where AM 253 fol. has been deposited ever since. The sammelband is, in short, another good example of paper 
and information in motion across space and time. But in addition to its paper in motion and modular use, the sammelband has some items which demonstrate the status of texts and their media (paper and otherwise) as material spaces with the power to rally the emotional ties that create a sense of identity in human communities.

Fol. 256r of the sammelband has several interesting inscriptions and two small paper slips pasted onto it, one of which is attached to the folio page only on its right edge, so it can be viewed on both its recto and its verso. The strange characters on these paper slips reproduce the texts of one of the Lead Books of El Sacromonte, a series of documents inscribed on lead discs found in some caves near Granada between 1595 and $1599 .{ }^{44}$ The unexpected discovery of these unusual texts and formats made quite an impact because they contained prophesies about the role of Granada in the subsequent development of Hispanic Christianity which conveniently matched the expectations of a monarchy that saw itself as the sword of Rome, charged with the mission of spreading the true faith all over the globe - an extension of Charles V's idea of universitas christiana, and Philip II's millenarian outlook. But in contrast to this narrative, the lead books also presented a new account of the origins of Christianity in the Iberian peninsula. It featured the names and deeds of some proto-martyrs, whose remains were also conveniently exhumed alongside some of the books, and immediately turned into venerated relics. Furthermore, the texts did not just proclaim that these martyrs were the first Christians sent to preach the Gospel in the Iberian peninsula, but that they were ethnic Arabs. And finally, the texts inscribed on some of the lead discs displayed a syncretic faith that sought to bring Islam and Christianity into doctrinal harmony. After a few years of intense controversies among scholars on their authenticity, the Vatican established that these doctrines were not just heretical, but that the books were a fraud too.

All the empirical and historical evidence about them suggests that they had been fabricated by someone with a good knowledge of Latin and Arabic, as well as an expert in the doctrinal intricacies of both Christian and Muslim theology. The languages of the texts include Arabic, Latin, Spanish and a fourth strange script that has not been deciphered yet, in the so-called Dumb Book, or Libro Mudo. The leaves of paper pasted onto Chacón's sammelband contain passages from this text, undoubtedly sent to him in the same way as they were sent to other expert scholars in Spain and abroad, with a view to their interpretation. The rest of the folio also bears Chacón's handwritten notes with other similar characters, and some drawings of the star-shaped Seal of Salomon, one of the main symbols that feature in the lead books.

There are some important aspects related to the fascinating story of the lead books which I have neither the time nor the space to discuss in greater detail but are nevertheless of interest for the current essay. One is the media employed: if the forgers wanted to come up with a credible set of texts supposedly dating from the first century

44 On the lead books, and their cultural and historical background, see MANUEL BARRIOS AGUILERA's La invención de los libros plúmbeos. Fraude, historia y mito (Granada: Servicio de Publicaciones de la Universidad, 2011). For the first full-length account in English of the lead books, see ELIZABETH DRAYSON's The Lead Books of Granada (New York and Basingstoke: Palgrave MacMillan, 2013). 
AD, they had to inscribe them upon durable media that could have successfully resisted the passage of a millennium and a half - certainly not paper, nor even parchment. The other one is that, although the authorship of the texts has not been established with absolute certainty, one of the most likely suspects is the Spanish Morisco Alonso del Castillo, an accomplished scholar well versed in Latin who also worked as a translator of Arabic diplomatic correspondence for Philip II and catalogued the well-furnished collection of Arabic manuscripts in the library of El Escorial. Last, but not least, scholarship agrees that, irrespective of its authorship, such a skilfully timed and sophisticated forgery was an attempt to reconcile Islam with Christianity and therefore to contribute to legitimising the presence of Moriscos on the Iberian peninsula. Indeed, it was to confirm them as the oldest of all cristianos viejos, since the texts established that these Arab Christians had been sent to evangelise the Iberian Roman population during the times of Emperor Nero. The lead books appeared at a time when there was much unrest among the Morisco community, which found itself under constant threat of expulsion. The entire project, therefore, amounted to an attempt to create a series of texts around which two very different communities could rally with a view to the creation of a common identity and the establishment of a peaceful coexistence. They failed, and in 1609 the Hispanic Moriscos were expelled from Spain once and for all.

Certain events related to the Hispanic Moriscos and their situation soon after the final defeat of Islam in the Iberian peninsula illustrate the relation between paper, identity and the emotions. The role of paper as a medium for communication and consequently for the establishment of communities and the emotional ties that generated and held them together is the subject of the last section of my essay.

\section{Memory and Identity}

The first part of Miguel de Cervantes' Don Quijote was originally published in Madrid in 1605, namely just a few years after the discovery of the Libros Plumbeos, in the midst of the furore they provoked, and only four years before the definitive expulsion of the Moriscos in 1609. At the end of chapter 8, the story is abruptly truncated in medias res, and chapter 9 opens with the narrator's lament that the author of the story he is recounting has left both himself and his reader frustratedly wanting for more. He then proceeds to tell how, as one day he was walking 'on the exchange [i.e. the market]' in the city of Toledo, 'a boy coming up to a certain mercer, offered to sell him a bundle of old papers he had in his hand' (pp. 74-75). The narrator hastens to add that since he had always had 'a strong propensity to read even those scraps [papeles rotos] that sometimes fly about the streets, I was led by this my natural curiosity, to turn over some of the leaves: I found them written in Arabic, which not being able to read, tho' I knew the characters, I looked about for some Portugeze Moor who should understand it.' ${ }^{45}$ The narrator finds a Morisco whose translation reveals that these papers

${ }^{45}$ Miguel DE Cervantes, The Histories and Adventures of the Renowned Don Quixote, trans. Tobias Smollett (New York: The Modern Library, 2004), 74-76. The Spanish original says morisco aljamiado, that is, a bilingual Moor who could read Arabic and speak Spanish. 
recorded 'The history of Don Quixote de la Mancha, written by Cid Hamete Benengeli, an Arabian author,' and from this moment on Cervantes devises the rest of his novel as the narrator's transcription of their translation by a bilingual Morisco from an originally Arabic manuscript penned by an imaginary Muslim author.

There are several aspects of this complex metanarrative device which strike the reader. In the first place Cide Hamete Benengeli is introduced by Cervantes as a historian who gathers information from the annals of La Mancha to compose his story with the adventures of Alonso Quijano. The second aspect of interest lies in the paper fragments (papeles rotos, literally, broken papers) which stand as scattered documentary ruins, or textual echoes of a pre-existing peninsular other: tokens for Muslim Iberia first, and then for the Moriscos after the demise of Islam in the south of Europe. Presenting a story as the translation from a manuscript in an alien language was not an infrequent narrative device in prose fiction, and above all in chivalric romance. But other than these literary antecedents and their parodic intent as part of a complex literary game, there is also a recognisable historical context for this serendipitous discovery of a bundle with paper documents in Arabic, which lends verisimilitude to Cervantes' fictional device. The episode takes place in a public market, but instead of using the most common Spanish words, mercado, Cervantes uses one of Arabic origin, alcaná. This market also happens to be in the city of Toledo, well known for its large communities of Jewish and Muslim converts - which explains why it was not difficult for the narrator to find a morisco aljamiado (i.e., a Spanish-speaking Muslim convert) to translate his broken papers. The mercer from whom he bought the papers was a sedero, namely a dealer in silk: traditionally one of the main exports of Muslim Iberia, an industry and a trade which significantly declined after the expulsion of the Moriscos, who were mostly responsible for its production and sale. Finally, the fact that the papers were about to be recycled by the mercer illustrates uses of paper other than for the registration of script, which confirms its nature as a supple and versatile material put to good use in a variety of industries.

In spite of the destruction of Arabic books and manuscripts which - with very few exceptions - had been decreed and systematically performed over the years after the Christian conquest, it was not infrequent to come across documents of this sort in Arabic, either recycled for other functions, or as books and records to be used in clandestinity by the Morisco community. A number of Arabic manuscripts, either on paper or parchment, circulated under the radar of the authorities, and when they became too dangerous to share, some of them were hidden to avoid destruction. Walled libraries and archives with Arabic manuscripts are indeed a category of their own, and several of them have been found over the past century and a half. Late in the nineteenth century (1886), 63 codices were discovered in Almonacid de la Sierra, the property of a Morisco bookseller who also hid the tools employed in the production 
and binding of his manuscripts. ${ }^{46}$ Around the same time, a Morisco Qur'an was found in a house undergoing demolition in central Granada. Other copies of the Qur'an, on parchment and paper, were found in 1961,1969 and 1993 in several different locations. Some of these documents date from the early years of the Christian conquest, whereas others are dated closer to the time of the definitive expulsion of the Moriscos in 1609. There are also remains of books that belonged to the Jewish community: the so-called Biblioteca de Barcarrota, found in 1992, consists of ten different books which belonged to a sixteenth-century Jewish convert, the physician Francisco de Peñaranda.

The next and final section of my essay is the story of the most recent of these finds. It is a modest, but very representative library found in Cútar, a small village perched in the mountains that overlook the Mediterranean coast in the south of Spain. During the refurbishment of an old house in 2003, workers found a niche behind a recently demolished wall with several documents in it: three manuscripts, one of them a copy of the Qur'an in parchment, plus several unbound paper documents, all carefully preserved in straw. During the last decades of Muslim Iberia, Cútar was part of the municipality of the Axarquía, which was swiftly occupied after the victory of the Catholic monarchs over the Muslim troops in Málaga in 1487. During the early years of the occupation, and in particular in distant villages in the mountains like Cútar, the Moorish population were allowed to preserve their social, religious and cultural institutions, naturally under the supervision of a Christian officer, until the situation changed drastically early in the sixteenth century with a decree that forced them into conversion or exile. In other words, for about a decade, namely around 1487-1501, Moors were allowed to preserve and use some of the institutions, documents and practices that recorded and performed their common linguistic, cultural and religious identity. ${ }^{47}$ These are the historical circumstances that lay behind the documents found in Cútar, whose owner appears to have been an alfaqui, that is, an expert in sharia, or Islamic law. For the small community in which he lived and worked, he was a spiritual guide, notary, lawyer, and also a scribe. The documents he preserved prove that he performed these functions during the first few years after the Christian conquest, as part of a community which felt increasingly under siege and constant surveillance.

There are some relevant analogies between the alfaquis situation and that of his community and the nature of the contractual culture described in the first section of my essay and the role of paper in it. Some of the alfaquis legal documents amount to a handbook of sorts for a small-town lawyer, registrar and notary public. They include

46 María Jesús Viguera Molins, 'Marco Socio-Cultural del Corán de Cútar,' in El Corán de Cútar. Estudio Introductorio, ed. MARÍA Jesús VIGUERA MOLINS (Sevilla: Fundación Tres Culturas del Mediterráneo, 2009), 15-45, see 35-36 for a list of some other findings.

47 Viguera Molins, 'Marco socio-cultural,' 16-19; María IsABel Calero SeCALL, 'Los manuscritos nazaríes de Cútar: el contenido,' in Los manuscritos nazaries de Cútar (Málaga). Documentos y estudios, ed. María Isabel CAlero SeCall et al. (Malaga: Servicio de Publicaciones de la Universidad de Málaga, 2016), 15-61, see 17; Esther Cruces Blanco, Ana DíAz SÁnCHEZ and Sonsoles GonzÁlez GarCíA, 'Manuscritos y documentos nazaríes conservados en el Archivo Histórico Provincial de Málaga,' in Los manuscritos nazaries de Cútar, ed. CALERO SECALL et al., 63-86, see 66-67, et passim for a material description of the documents and the process of their restoration. 
forms and protocols, norms on marriage and death taxes, basic arithmetic for the measurement and weight of goods and land involved in legal disputes about ownership and trade, and in general information on the traditions of the Prophet, that is, the interpretation of Islamic law - the common legal framework, and the highest source of authority which could legitimise the value and function of all these documents. These walled papers are a documentary micro-cosmos of methods for the regulation and administration of everyday life in a small Muslim community.

The papers themselves hold the key to the reason they were hidden, since they also document the advance of the Christian troops and a series of forced conversions. Interspersed in some of the manuscripts with legal and quantitative data, the alfaqui also registered his personal response to the events that eventually led to the suppression of his community. 'Christians conquered Vélez during the spring of $892 / 1487$,' says one of these brief manuscript notes, 'and the Lord of Castile conquered Granada in the winter of $897 / 1492$, and he broke his pact and baptised the people of Granada.' He concludes with a curse on those who had inflicted such pain and loss upon Muslim Iberia. ${ }^{48}$

As is frequently the case with paper documents, some of the most common methods for their dating involve their watermarks, the type of script used and naturally their language. The watermarks of the documents found in Cútar prove that some of the older papers were produced by Muslims, while the most recent were of Christian origin. After the occupation, the alfaqui had no choice but to use Christian paper to register a few poetic elegies on the loss of Muslim Iberia. In contrast to other border poems on the confrontation between Christians and Muslims, which are usually written in Classical Arabic, these endechas are written in an Andalusian dialect. Carmen Barceló transcribed and translated the poems into Spanish in 2012 and suggests that they must have been composed within a time frame that starts circa 1485-87, namely, during the years of the siege and conquest of Málaga, and concludes with the decree of 1501 that forced Hispanic Muslims into conversion or exile. One of the poems is actually dated by the alfaqui himself as what he calls the 'year of oppression and mistreatment. ${ }^{, 49}$

There is a very revealing contrast between this lament in dialectal Andalusian Arabic which had to lay hidden for more than 500 years to avoid destruction, and another very different kind of paper document. Petrus Bosca's Latin De victoria Malachitana, which celebrates this victory over Islam, is a typically humanist oration as it also constitutes an early case of news in print. An 11-page pamphlet in quarto, the oration was delivered and printed in Rome in October 1487, soon after the events it recounted - the capitulation of Málaga was signed on 18 August 1487. Bosca celebrates

48 Vol. L-14030, fol. 11v/256, quoted in CALERO SECALL, 'Los manuscritos nazaríes de Cútar,' 46. The alfaqui also recorded news on current events which he must have contemplated through an apocalyptic lens - such as an earthquake in the city of Málaga in 1494, two years after the definitive fall of Granada, L-14030, fol. 11v/256, quoted in CALERO SECALL, 'Los manuscritos nazaríes de Cútar,' 47.

${ }^{49}$ L14030, fol. 8v/247, in CALERo SECALL, 'Los manuscritos nazaríes de Cútar,' 29; see also 60, 62. 
the conquest of Málaga as a victory for global Christianity and a decisive step on the path towards the culmination of the Hispanic project of universitas christiana.

The poems of Cútar and the Roman pamphlet are, therefore, very good examples of the recording of emotional responses generated by the same event, in very different formats and tones, from two totally different perspectives. One is a lament, recorded in a manuscript, for very private and personal use by the alfaqui and perhaps also his diminishing community, which records a keen sense of loss. It is very telling that this document had to remain walled for half a millennium in order to survive, whereas the Christian celebration trumpeted its victory through a printed and very public document that was distributed all over Europe: the ISTC catalogue records 37 surviving copies. ${ }^{50}$

The manuscripts of Cútar and the community that produced and used them are just one of myriad cases which confirm that, like people, paper can also become subject to displacement and loss: adventurous travellers, merchants, diplomats, collectors, explorers, migrants and exiles, all engaged in the production and circulation of paperbased documents. Alongside falsification, theft and exchange, paper also became the victim of violent elimination. In addition, there were other less aggressive practices which consisted of symbolic acts of cultural and political appropriation, in particular when this involved the registration of history and the generation of textual and symbolic spaces that represented the entire community. ${ }^{51}$

\section{Coda: Paper Fetishism}

State administration and politics, in both its domestic and international dimensions, are of course recorded in institutional or state archives whose documents are a source of information for historians. At the same time, these archives also constitute cultural icons in their own right, repositories of political and cultural capital that represent the community, the institution or the nation that invests a significant amount of emotional value in their symbolic power. One of the symptoms of the wave of nationalism that spread throughout Europe in the nineteenth century was the systematic creation of archival records, commissions for the research, collection and classification of documents, and also the publication of critical editions of the most significant among them. Some of these documents, were (are) then displayed permanently in museums or in temporary exhibitions, thus entering the public sphere as significant constituents within a larger narrative of common identity. In contrast to this well-established use, new research increasingly tends to demonstrate that these documentary repositories

\footnotetext{
50 'Bosca, Petrus, Oratio de victoria Malachitana, 22 Oct. 1487,' entry in BRITISH LIBRARY, Incunabula Short Title Catalogue, https://data.cerl.org/istc/ib01039000.

51 The Prize Papers Project, http://www.prizepapers.de/, which is in the process of digitising and classifying the enormous amount of documents confiscated by the British navy from enemy ships during wartime, will without any shadow of a doubt yield extremely interesting material for historians of this kind of documents and related disciplines.
} 
also record the hybrid foundations of all cultural, national and religious identities thus yielding a counternarrative that contradicts the claims of traditional nationalism. ${ }^{52}$

New electronic media and the global spread of the Internet have laid the ground for the emergence of a heterogeneous constellation of online communities in the same way as it has also come to reinforce more traditional, even atavistic, narratives of identity, as Debray predicted. But, thanks to digitisation, it has also returned paperbased archives to the foreground, and online libraries have developed the potential to bring pdf copies of rare and old books to readers the world round. The wealth of digitally remediated electronic copies of paper documents and paper artefacts has paradoxically highlighted the ubiquity of paper in European and global history and facilitated new interpretations of its fundamental roles. We may find that digitisation will end up re-fetishising books and paper documents after all.

52 For an excellent introduction to the most recent secondary literature and the most important issues related to the cultural and social history of the early modern archive, see ALEXANDRA WALSHAM's 'The Social History of the Archive: Record-Keeping in Early Modern Europe,' in Past and Present, Supplement 11 (2016): 9-48, and in general the entire special issue of Past and Present. 